\title{
MIR130A wt Allele
}

National Cancer Institute

\section{Source}

National Cancer Institute. MIR130A wt Allele. NCI Thesaurus. Code C82077.

The human MIR130A wild-type allele is located in the vicinity of $11 \mathrm{q} 12.1$ and is approximately 88 bases in length. This allele, which encodes MIR130A pre-miRNA, plays a role in the regulation of gene expression. Alteration in the expression of this gene is associated with the development of hepatocellular carcinoma. 